\title{
Angiotensin I-Converting Enzyme Inhibitory Activities of Synthetic Peptides Related to the Tandem Repeated Sequence of a Maize Endosperm Protein
}

\author{
Susumu Maruyama, Shinsuke Miyoshi, ${ }^{*}$ Toshiyuki KaneKo* \\ and Hideoki TaNAKA \\ Fermentation Research Institute, Tsukuba, Ibaraki 305, Japan \\ * Central Research Laboratories, Showa Sangyo Co., Ltd., \\ Funabashi, Chiba 273, Japan
}

Received November 10,1988

\begin{abstract}
Peptides that exist in the tandem repeated region formed by six units of Pro-Pro-Pro-Val-HisLeu in a maize endosperm protein $\gamma$-zein were chemically synthesized, and the angiotensin I-converting enzyme inhibitory activities of these peptides were investigated. Synthetic Val-His-Leu-Pro-Pro-Pro inhibited the enzyme $\left(\mathrm{IC}_{50}=\mathbf{2 0 0} \mu \mathrm{M}\right)$. Other synthetic fragment peptides, Val-His-Leu-Pro-Pro $\left(\mathrm{IC}_{50}=18 \mu \mathrm{M}\right)$ and Leu-Pro-Pro $\left(\mathrm{IC}_{50}=\mathbf{9 . 6} \mu \mathrm{M}\right)$ inhibited the enzyme more potently. Then the native hexapeptide Val-His-Leu-Pro-Pro-Pro was purified from a thermolysin hydrolysate of $\gamma$-zein.

The antihypertensive activities of synthetic Val-His-Leu-Pro-Pro and Leu-Pro-Pro were also investigated. These peptides, when intravenously administered to anesthetized rats at $125 \mathrm{mg} / \mathrm{kg}$ (LeuPro-Pro) or $160 \mathrm{mg} / \mathrm{kg}$ (Val-His-Leu-Pro-Pro), antagonized the rats' pressor response to angiotensin I.
\end{abstract}

Angiotensin I-converting enzyme [EC 3.4.15.1] (ACE) catalyzes both the production of the vasoconstrictor angiotensin II and the inactivation of the vasodilator bradykinin. Inhibitors of ACE were first obtained from the venom of snakes such as Bothrops jararaca ${ }^{1,2)}$ and Agkistrodon halys blomhoffii. ${ }^{3)}$ Many of these inhibitors have Pro-Pro or Ala-Pro sequence at their C-terminal. In particular, some of these inhibitors have the X-Ile-Pro-Pro ( $\mathrm{X}=\mathrm{Gln}$ or Lys) sequence at their C-terminal.

We previously reported ACE inhibitors from the tryptic hydrolysate of bovine casein. ${ }^{4 \sigma 6)}$ Recently, we attempted to produce ACE inhibitors from another food protein, a maize endosperm protein. The most abundant storage protein fraction of maize (Zea mays) endosperm is composed of a family of alcoholsoluble proteins called zeins. The other major storage protein fraction is glutelin-2, which is also referred to as alcohol-soluble reduced glutelin (ASG) and zein-like protein. A major component of this fraction is a 28 -kilodalton protein, which is referred to as the 28-kilodalton glutelin-2, water-soluble ASG, or $\gamma$-zein. ${ }^{7)}$ In this paper, we follow the terminology adopted by Esen, calling this protein $\gamma$-zein. ${ }^{7)}$ This protein has a repeated region formed by six units of the sequence Pro-Pro-Pro-Val-HisLeu in the N-terminal region. ${ }^{8,9)}$ We noted the sequence Val-His-Leu-Pro-Pro in this region. Thus, we investigated ACE inhibitory and antihypertensive activities of related synthetic peptides and we tried to isolate these peptides from an enzymatic hydrolysate of $\gamma$-zein.

\section{Materials and Methods}

Materials. Rabbit lung acetone powder and thermolysin were purchased from the Sigma Chemical Co. Hip-HisLeu, $t$-butyloxycarbonyl (Boc-) amino acids, and other reagents for the liquid phase peptide synthesis were ob-

Abbreviations: Hip-His-Leu, hippuryl-L-histidyl-L-leucine; $\mathrm{IC}_{50}$, the concentration of an ACE inhibitor required to inhibit $50 \%$ of the ACE activity. All amino acids mentioned were of the L-configuration. 
tained from the Peptide Institute, Inc. (Osaka, Japan). Boc- amino acids, resins, and other reagents for the solid phase peptide synthesis were purchased from Applied Biosystems, Inc.

Synthesis of peptides. Leu-Pro-Pro was synthesized by the liquid phase method, using $N, N$-dimethylformamide as a solvent with $N, N^{\prime}$-dicyclohexylcarbodiimide and Ihydroxybenzotriazole as coupling reagents, as previously described. ${ }^{10)}$ Other peptides described in this paper were synthesized by the solid phase method with a 430A Peptide Synthesizer (Applied Biosystems, Inc.). Hydrogen fluoride was used for removing the side chain protecting groups and for cleaving peptides from their solid support. The synthesized peptides were purified by high performance liquid chromatography (HPLC) on a reverse phase column of Aquapore TM Prep-10 (Applied Biosystems, Inc.) with a gradient of $\mathrm{CH}_{3} \mathrm{CN}(3.5$ to $67 \%$ ) in $0.1 \%$ trifuoroacetic acid.

Purification of Val-His-Leu-Pro-Pro-Pro from a thermolysin hydrolysate of $\gamma$-zein. $\gamma$-Zein was separated from maize endosperm meal by the method of Esen. ${ }^{7,11)}$ Four hundred $\mathrm{mg}$ of this $\gamma$-zein fraction was washed with $0.05 \mathrm{~N}$ $\mathrm{NaOH}$, the protein was then collected with a PM-10 membrane (Amicon Co.). This protein was dissolved in $25 \mathrm{ml}$ of Tris- $\mathrm{HCl}(50 \mathrm{~mm}, \mathrm{pH} 8.2)$ containing $5 \mathrm{mM} \mathrm{CaCl}_{2}$, and then $20 \mathrm{mg}$ of thermolysin was added. After $40 \mathrm{hr}$ of incubation at $37^{\circ} \mathrm{C}$, the $\mathrm{pH}$ of the reaction mixture was adjusted to 1.7 by the addition of $1 \mathrm{~N} \mathrm{HCl}$. The precipitate and polypeptide were removed by ultrafiltration with PM10 membrane, and the filtrate was adjusted to $\mathrm{pH} 7.0$ with $\mathrm{NaOH}$. The sample was concentrated and applied to a column $(1.6 \times 70 \mathrm{~cm})$ of Sephadex LH-20 (Pharmacia Fine Chemicals) and eluted with distilled water at a flow rate of $0.55 \mathrm{ml} / \mathrm{min}$. Then the fraction containing Val-His-LeuPro-Pro-Pro was traced by HPLC using synthetic Val-HisLeu-Pro-Pro-Pro as a standard, and the fraction containing Val-His-Leu-Pro-Pro-Pro was collected. This fraction was applied to a column $(1.6 \times 20 \mathrm{~cm})$ of SP-Toyopearl $650 \mathrm{~S}$ (Tosoh Co., Ltd.) and eluted with a linear gradient of $\mathrm{NaCl}(0$ to $0.3 \mathrm{M})$ in $5 \mathrm{~mm}$ sodium acetate buffer $(\mathrm{pH} 4.0)$ at a flow rate of $1.6 \mathrm{ml} / \mathrm{min}$. The fractions, which contain Val-His-Leu-Pro-Pro-Pro, were collected and concentrated. The sample was desalted on a Sephadex LH-20 column $(1.6 \times 70 \mathrm{~cm})$ and concentrated. The desalted sample was applied to a column (Radial-PAK $\mathrm{C}_{8}$, Waters Inc.) for HPLC, which was eluted with phosphate buffer $\left(10 \mathrm{mM} \mathrm{KH}_{2} \mathrm{PO}_{4}, 50 \mathrm{mM} \mathrm{Na}_{2} \mathrm{SO}_{4}, \mathrm{pH} 2.5\right) / \mathrm{CH}_{3} \mathrm{CN}(40: 60$, $\mathrm{v} / \mathrm{v}$ ) at a flow rate of $1 \mathrm{ml} / \mathrm{min}$, with monitoring of the absorbance at $210 \mathrm{~nm}$. Purified Val-His-Leu-Pro-Pro-Pro was collected and salts were removed by a Sep-PAK $C_{18}$ cartridge (Waters Inc.).

Analysis of peptides. The purity of each synthetic peptide was checked by HPLC, as previously described. ${ }^{10)}$ The amino acids of each peptide were analyzed with a Hitachi
835 amino acid analyzer after hydrolysis with $6 \mathrm{~N} . \mathrm{HCl}$ at $110^{\circ} \mathrm{C}$ for $24 \mathrm{hr}$ under a vacuum. The molecular formula of each peptide was confirmed from its fast atom bombardment mass spectrum (FAB-MS) obtained with a JEOL HX-110 spectrometer.

The sequence of the peptide, which was purified from a thermolysin hydrolysate of $\gamma$-zein, was analyzed by automated Edman degradation using a $477 \mathrm{~A}$ Protein Sequencer (Applied Biosystems, Inc.).

In vitro assay for $A C E$ inhibitory activity. Assay were done spectrophotometrically, using $5 \mathrm{~mm}$ Hip-His-Leu as a substrate by a modification of the method of Cushman and Cheung, as described in our previous report. ${ }^{5)}$ The ACE used in this experiment was partially purified on hydroxylapatite from crude ACE, which had been extracted from rabbit lung acetone powder.

Measurement of the pressor response to angiotensin I in anesthetized rats. Groups of 3 or 4 male Wistar rats, each weighing $200 \mathrm{~g}$, were used. All the rats were anesthetized by intraperitoneal administration of urethane at $1.5 \mathrm{~g} / \mathrm{kg}$. The carotid artery blood pressure was measured with a pressure transducer (SCK-590, Nihon Kohden). Drugs were dissolved in saline, and injected into the femoral vein, which was cannulated with polyethylene tubing. Before the experiment, hexamethonium $(5 \mathrm{mg} / \mathrm{kg}$ ) was administered intravenously to all the anesthetized rats to eliminate the effects of another regulator which is not related to the renin-angiotensin system.

\section{Results}

\section{ACE inhibitory activity of Val-His-Leu-Pro- Pro-Pro and related peptides}

The analytical data for the synthetic peptides are summarized in Table I. The amino acid ratio of each peptide was identical with the theoretical value. The $(\mathrm{M}+\mathrm{H})^{+}$of each peptide appeared at $m / z$ of the theoretical value in the FAB-MS.

As shown in Table II, the inhibitory activity of the synthetic hexapeptide Val-His-Leu-ProPro-Pro was not potent. However, the pentapeptide Val-His-Leu-Pro-Pro, which lacks the C-terminal proline in the hexapeptide, inhibited ACE about 10 times more potently. In addition, the tripeptide Leu-Pro-Pro, which has already been reported by Kimura et al. as a bradykinin potentiator, ${ }^{12)}$ was far more potent than the corresponding tetrapeptide Leu-ProPro-Pro. 
Table I. Analytical Data for Synthetic Peptides

\begin{tabular}{|c|c|c|c|c|c|c|}
\hline \multirow{2}{*}{$\begin{array}{l}\text { Peptide } \\
\text { Val-His-Leu-Pro-Pro-Pro }\end{array}$} & \multirow{2}{*}{$\begin{array}{c}{[\alpha]_{\mathrm{D}}^{25}\left(^{\circ}\right)} \\
\left(\mathrm{H}_{2} \mathrm{O}\right) \\
-192 \\
(c=0.4)\end{array}$} & \multicolumn{4}{|c|}{$\begin{array}{c}\text { Amino acid ratio in } \\
\mathrm{HCl} \text { hydrolysate }\end{array}$} & \multirow{2}{*}{$\begin{array}{l}\text { FAB-MS }(m / z) \\
659(\mathrm{M}+\mathrm{H})^{+}\end{array}$} \\
\hline & & \multirow{2}{*}{\multicolumn{2}{|c|}{$\begin{array}{ll}\text { Val } & 1.00 \\
\text { Leu } & 1.04 \\
\text { Val } & 1.00 \\
\text { Leu } & 1.18\end{array}$}} & \multirow{2}{*}{\multicolumn{2}{|c|}{$\begin{array}{ll}\text { His } & 0.98 \\
\text { Pro } & 3.11 \\
\text { His } & 0.97 \\
\text { Pro } & 1.95\end{array}$}} & \\
\hline Val-His-Leu-Pro-Pro & $\begin{array}{c}-155 \\
(c=0.3)\end{array}$ & & & & & $562(\mathrm{M}+\mathrm{H})^{+}$ \\
\hline Leu-Pro-Pro-Pro & $\begin{array}{c}-254 \\
(c=0.3)\end{array}$ & Leu & 1.00 & Pro & 2.83 & $423(\mathrm{M}+\mathrm{H})^{+}$ \\
\hline Leu-Pro-Pro & $\begin{array}{c}-165 \\
(c=0.2)\end{array}$ & Leu & 1.00 & Pro & 1.92 & $326(\mathrm{M}+\mathrm{H})^{+}$ \\
\hline Val-His-Ile-Pro-Pro & $\begin{array}{c}-136 \\
(c=0.1)\end{array}$ & $\begin{array}{l}\text { Val } \\
\text { Ile }\end{array}$ & $\begin{array}{l}1.00 \\
1.03\end{array}$ & $\begin{array}{l}\text { His } \\
\text { Pro }\end{array}$ & $\begin{array}{l}0.91 \\
1.84\end{array}$ & $562(\mathrm{M}+\mathrm{H})^{+}$ \\
\hline Val-His-Leu-Ala-Pro & $\begin{array}{c}-100 \\
(c=0.2)\end{array}$ & $\begin{array}{l}\text { Val } \\
\text { Leu } \\
\text { Pro }\end{array}$ & $\begin{array}{l}1.00 \\
1.12 \\
1.00\end{array}$ & $\begin{array}{l}\text { His } \\
\text { Ala }\end{array}$ & $\begin{array}{l}0.95 \\
1.09\end{array}$ & $536(\mathrm{M}+\mathrm{H})^{+}$ \\
\hline His-Leu-Pro-Pro-Pro-Val & $\begin{array}{c}-218 \\
(c=0.3)\end{array}$ & $\begin{array}{l}\text { His } \\
\text { Pro }\end{array}$ & $\begin{array}{l}1.00 \\
3.09\end{array}$ & $\begin{array}{l}\text { Leu } \\
\text { Val }\end{array}$ & $\begin{array}{l}1.08 \\
1.00\end{array}$ & $659(\mathrm{M}+\mathrm{H})^{+}$ \\
\hline Leu-Pro-Pro-Pro-Val-His & $\begin{array}{c}-228 \\
(c=0.2)\end{array}$ & $\begin{array}{l}\text { Leu } \\
\text { Val }\end{array}$ & $\begin{array}{l}1.00 \\
1.00\end{array}$ & $\begin{array}{l}\text { Pro } \\
\text { His }\end{array}$ & $\begin{array}{l}3.05 \\
1.03\end{array}$ & $659(\mathrm{M}+\mathrm{H})^{+}$ \\
\hline Pro-Pro-Pro-Val-His-Leu & $\begin{array}{c}-204 \\
(c=0.3)\end{array}$ & $\begin{array}{l}\text { Pro } \\
\text { His }\end{array}$ & $\begin{array}{l}2.85 \\
0.99\end{array}$ & $\begin{array}{l}\text { Val, } \\
\text { Leu }\end{array}$ & $\begin{array}{l}1.00 \\
1.06\end{array}$ & $659(\mathrm{M}+\mathrm{H})^{+}$ \\
\hline
\end{tabular}

Table II. ACE INHIBITORY ACTIVITy of Val-HisLeu-Pro-Pro-Pro and Related PePtides

\begin{tabular}{cc}
\hline Peptide & $\mathrm{IC}_{50}(\mu \mathrm{M})$ \\
\hline Val-His-Leu-Pro-Pro-Pro & 200 \\
Val-His-Leu-Pro-Pro & 18 \\
Leu-Pro-Pro-Pro & 1000 \\
Leu-Pro-Pro & 9.6 \\
Val-His-Ile-Pro-Pro & 10 \\
Val-His-Leu-Ala-Pro & 4.5 \\
\hline
\end{tabular}

\section{Production of hexapeptide Val-His-Leu-Pro- Pro-Pro from $\gamma$-zein}

Figure 1A shows the Sephadex LH-20 chromatogram of a thermolysin hydrolysate of $\gamma$ zein. The fraction, which contains Val-HisLeu-Pro-Pro-Pro, was further fractionated by SP-Toyopearl 650S chromatography and subsequent Sephadex LH-20 chromatography. In this step, the sample contained at least 3 kinds of peptides. Then the sample was further purified by HPLC. Finally, about $50 \mu \mathrm{g}$ of peptide was obtained from $400 \mathrm{mg}$ of $\gamma$-zein fraction. Figure $1 \mathrm{~B}$ shows the HPLC chromatogram of this purified sample. The amino acid composition of this sample hydrolyzed with
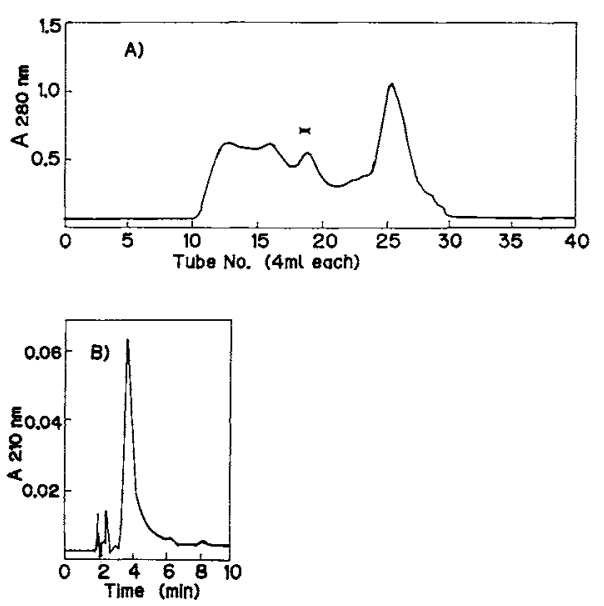

Fig. 1. Purification of Val-His-Leu-Pro-Pro-Pro from a Thermolysin Hydrolysate of $\gamma$-Zein.

A) All of a thermolysin hydrolysate of $\gamma$-Zein was chromatographed on a Sephadex LH-20 column $(1.6 \times 70 \mathrm{~cm})$. The No. 19 fraction was collected. The sample was further purified by ion exchange chromatography and subsequent HPLC.

B) Purified hexapeptide Val-His-Leu-Pro-Pro-Pro was chromatographed by HPLC. Conditions for HPLC: column, Radial-PAK $\mathrm{C}_{8}$; mobile phase, phosphate buffer (10 $\left.\mathrm{mM} \mathrm{KH}_{2} \mathrm{PO}_{4}, 50 \mathrm{mM} \mathrm{Na}_{2} \mathrm{SO}_{4}, \mathrm{pH} 2.5\right) / \mathrm{CH}_{3} \mathrm{CN}(40: 60$, $\mathrm{v} / \mathrm{v}$ ); flow rate, $1 \mathrm{ml} / \mathrm{min}$; detector, UV $210 \mathrm{~nm}$. See the details in this text. 
$6 \mathrm{~N} \mathrm{HCl}$ was $\mathrm{Val}(1.12)$, His $(0.86)$, Leu (1.00), Pro (2.67). This value closely resembled the theoretical value. The $(\mathrm{M}+\mathrm{H})^{+}$of this sample appeared at $m / z$ 659, identical with the theoretical value, in the FAB-MS. By automated Edman degradation the following PTHamino acids were consecutively released from this sample: (1) Val $(5.9 \mathrm{nmol})$, (2) His (0.69 nmol), (3) Leu (3.1 nmol), (4) Pro (2.4 nmol), (5) Pro $(0.91 \mathrm{nmol}),(6)$ Pro $(0.37 \mathrm{nmol})$. From these results, we consider this peptide to be the hexapeptide Val-His-Leu-Pro-Pro-Pro.
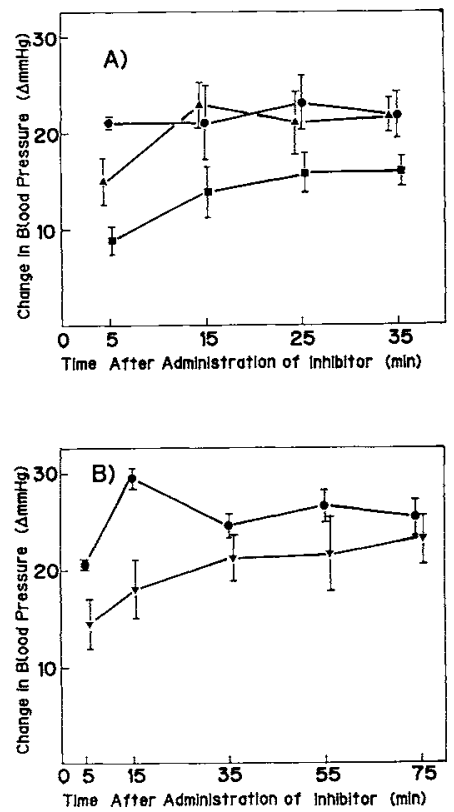

Fig. 2. Inhibitory Effects of Leu-Pro-Pro and Val-HisLeu-Pro-Pro on the Pressor Response to Angiotensin I in Hexamethonium-treated, Anesthetized Rats.

Five minutes before the experiment, hexamethonium $(5 \mathrm{mg} / \mathrm{kg}$ ) was administered intravenously to all the anesthetized rats. At zero time, an inhibitor (saline or synthetic peptide) was administered intravenously, and then, at the times indicated, $100 \mathrm{ng} / \mathrm{kg}$ of angiotensin I was administered intravenously. This figure shows the change in the blood pressure, i.e., $\Delta \mathrm{mmHg} . \Delta \mathrm{mmHg}$ was calculated as follows: $\Delta \mathrm{mmHg}=$ mean blood pressure, $\mathrm{mmHg}$ (after administration of angiotensin I)-mean blood pressure, mmHg (before administration of angiotensin I). A) The effects of Leu-Pro-Pro. B) The effects of Val-His-LeuPro-Pro.

- - control (saline); - $\mathbf{-}, 40 \mathrm{mg} / \mathrm{kg}$ of Leu-ProPro; - - $125 \mathrm{mg} / \mathrm{kg}$ of Leu-Pro-Pro; - $\boldsymbol{\nabla}$ $160 \mathrm{mg} / \mathrm{kg}$ of Val-His-Leu-Pro-Pro.
Antihypertensive activity of Leu-Pro-Pro and Val-His-Leu-Pro-Pro

The antihypertensive activities of synthetic Leu-Pro-Pro and Val-His-Leu-Pro-Pro were investigated in anesthetized rats. As shown in Fig. 2A, Leu-Pro-Pro (40 or $125 \mathrm{mg} / \mathrm{kg}$ ), which was administered intravenously to the rats treated with hexamethonium $(5 \mathrm{mg} / \mathrm{kg})$, antagonized the pressor response to intravenously injected angiotensin I $(100 \mathrm{ng} / \mathrm{kg})$. Val-His-Leu-Pro-Pro $(160 \mathrm{mg} / \mathrm{kg})$ also antagonized the pressor response to angiotensin I (Fig. 2B). The effects of these peptides were most apparent within $15 \mathrm{~min}$ after administration.

\section{Discussion}

As many of the ACE inhibitors derived from the venom of snakes have the sequence IlePro-Pro at their C-terminal, we synthesized Val-His-Ile-Pro-Pro (the antepenultimate amino acid of Val-His-Leu-Pro-Pro was replaced by Ile). This peptide was about 2 times more potent as an ACE inhibitor than ValHis-Leu-Pro-Pro (Table II). In addition, we synthesized Val-His-Leu-Ala-Pro, because it is considered that the peptides with the Cterminal sequence Ala-Pro are more effective as ACE inhibitors than the peptides with the sequence Pro-Pro. The inhibitory activity of this peptide, Val-His-Leu-Ala-Pro, was 4 times more potent than Val-His-Leu-Pro-Pro (Table II).

We also synthesized other hexapeptides such as His-Leu-Pro-Pro-Pro-Val, Leu-ProPro-Pro-Val-His, and Pro-Pro-Pro-Val-HisLeu (Table III). Although His-Leu-Pro-ProPro-Val and Leu-Pro-Pro-Pro-Val-His could

Table III. ACE INHIBITORY ACTIVITY OF OTHER SYNTHETIC HEXAPEPTIDES

\begin{tabular}{cr}
\hline Peptide & $\mathrm{IC}_{50}(\mu \mathrm{M})$ \\
\hline Val-His-Leu-Pro-Pro-Pro & 200 \\
His-Leu-Pro-Pro-Pro-Val & $\gg 1000$ \\
Leu-Pro-Pro-Pro-Val-His & $>1000$ \\
Pro-Pro-Pro-Val-His-Leu & 110 \\
\hline
\end{tabular}


scarcely inhibit ACE, Pro-Pro-Pro-Val-HisLeu, the C-terminal dipeptide of which is identical with the C-terminal dipeptide of angiotensin I, inhibited ACE $\left(\mathrm{IC}_{50}=110 \mu \mathrm{M}\right)$. However, the production of Pro-Pro-Pro-Val-HisLeu from $\gamma$-zein may be impossible because of the difficulty in hydrolyzing only Leu-Pro bonds with proteinases.

Thermolysin hydrolyzes the peptide bonds of proteins and peptides at the amino sites of hydrophobic amino acids with bulky side chains. However, it has been reported that this enzyme fails to hydrolyze the peptide bond if a proline residue is present at the $\mathrm{P}_{2}{ }^{\prime}$ site. ${ }^{13)}$ Therefore we used thermolysin to hydrolyze the peptide bond at the amino site of valine of -(Pro-Pro-Pro-Val-His-Leu) $)_{\bar{n}}$. Val-His-LeuPro-Pro-Pro was thus isolated. For the purpose of producing a much more potent ValHis-Leu-Pro-Pro from a less potent Val-HisLeu-Pro-Pro-Pro, we tried to hydrolyze this hexapeptide with carboxypeptidases such as carboxypeptidase Y (Oriental Yeast Co., Ltd.) and Penicillium janthinellum acid carboxypeptidase (Takara Shuzo Co., Ltd.). However, these carboxypeptidases could not liberate proline.

Leu-Pro-Pro and Val-His-Leu-Pro-Pro antagonized the pressor response to angiotensin I. ACE inhibitors with the C-terminal sequence Pro-Pro resist hydrolysis by ACE and carboxypeptidases, however, a large amount of peptides were required in this experiment.
These peptides may be hydrolyzed with other proteases or adsorbed by cells in the blood vessel. Although the antihypertensive activities of these peptides were rather weak, these sequences exist in a food protein. Therefore, we are investigating the method to produce these peptides efficiently from food protein.

\section{References}

1) S. H. Ferreira, D. C. Bartelt and L. J. Greene, Biochemistry, 9, 2583 (1970).

2) M. A. Ondetti, N. J. Williams, E. F. Sabo, J. Pluščec, E. R. Weaver and O. Kocy, Biochemistry, 10, 4033 (1971).

3) H. Kato and T. Suzuki, Biochemistry, 10, 972 (1971).

4) S. Maruyama and H. Suzuki, Agric. Biol. Chem., 46, 1393 (1982).

5) S. Maruyama, K. Nakagomi, N. Tomizuka and H. Suzuki, Agric. Biol. Chem., 49, 1405 (1985).

6) S. Maruyama, H. Mitachi, J. Awaya, M. Kurono, N. Tomizuka and H. Suzuki, Agric. Biol. Chem., 51, 2557 (1987).

7) A. Esen, J. Cereal Sci., 5, 117 (1987).

8) A. Esen, J. A. Bietz, J. W. Paulis and J. S. Wall, Nature, 296, 678 (1982).

9) S. Prat, J. Cortadas, P. Puigdomenech and J. Palau, Nucl. Acids Res., 13, 1493 (1985).

10) S. Maruyama, H. Mitachi, H. Tanaka, N. Tomizuka and H. Suzuki, Agric. Biol. Chem., 51, 1581 (1987).

11) A. Ésen, Plant Physiol., 80, 623 (1986).

12) K. Kimura, H. Kato, S. Sakakibara and T. Suzuki, "Proc. Am. Pept. Symp." ed. by L. Saul, Gordon and Breach, New York, 1972, pp. $261 \sim 268$.

13) H. Matsubara, A. Singer and R. M. Sasaki, Biochem. Biophys. Res. commun., 34, 719 (1969). 